\title{
12
}

\section{The Decolonisation of Community Development in Haut-Katanga and the Zambian Copperbelt, 1945-1990}

\author{
Miles LaRmer \& RACHel TAYLOR
}

\section{Introduction}

The urban societies of the Central African Copperbelt have been conceptualised as sites of social transformation by academics, states, mining companies and Copperbelt residents alike, who imagined a largely static rural 'tradition' being replaced by urban 'modernity'. In Haut-Katanga, Union Minière du Haut-Katanga (UMHK) sought to build a stable urban workforce from the 1920s, while across the border in Northern Rhodesia colonial and company officials were slower in adapting this policy. ${ }^{1}$ Nevertheless, by the 1950s mining companies across the region saw this transformation to urban 'modernity' as necessary, but also dangerous. The loss of the traditional chiefly authority they believed was key to rural social order created the danger of a breakdown in traditional morality in the growing mining towns. They employed social workers - initially Europeans - to guide workers and their families towards what were considered new and desirable forms of respectable family life, and away from the perceived immorality, deviance and delinquency the authorities feared would result from unguided urbanisation. In the late-colonial period it was increasingly recognised that effective social intervention would come from 'advanced' members of African societies themselves, familiar with societal 'custom'

1 For inter-war Belgian Congo see Amandine Lauro, 'Maintenir l'ordre dans la colonie-modèle: Notes sur les désordres urbains et la police des frontières raciales au Congo Belge (1918-1945)', Crime, Histoire \& Sociétés / Crime, History E Societies, 15 (2011), pp. 97-121. 
but also educated in European languages, domestic styles and academic approaches. This chapter traces the outlines of community development and social intervention in mining communities across the Copperbelt in the second half of the twentieth century. It focuses on the 1960s to the 1980s, a period hitherto neglected by researchers on African social welfare, in which community development programmes were placed in the hands of senior African social workers under the direction of nationalised mining and other state-owned companies.

Social work across the Copperbelt shared some common concerns and themes. On both sides of the border, the need to ensure a productive (male) mineworker was seen as resting on a stable and modernised nuclear family life. Employed by states and mine companies, social workers provided relationship advice, enabled leisure opportunities and combatted 'social ills' such as alcoholism, crime and marriage breakdown. 'Community development' initiatives sought to shape every aspect of family life, from marital relations to household economy, from cleanliness and nutrition to child rearing. Ostensibly technocratic initiatives to manage communities were infused with patriarchal notions of morality in which 'respectable' families were distinguished from those requiring intervention and sanction. There were important differences, however. In Katanga, social work and social welfare programmes were more established, as Union Minière had played a pioneering role in training and employing such agents from the 1930s. While UMHK's system of 'authoritarian paternalism' expanded in the postSecond World War period to encompass every aspect of community life, mine companies in Northern Rhodesia only embraced the importance of social work as they belatedly accepted the realities of 'stabilisation' from the 1950s, creating a fragmented system of social intervention compared to that in Haut-Katanga.

Yet social work did not remain simply a colonial imposition. While the first generation of social workers were Europeans, it was increasingly recognised that trained African social workers, sufficiently indigenous to understand custom but educated enough to provide guidance on how to adjust to city life, were crucial to maintain social order. In the context of decolonisation and early independence, companies and states rapidly expanded the training and professionalisation of social workers and community development officers in the booming mine towns of the 1950s and 1960s.

The rapid Africanisation of social work in mining communities raises important questions. How did the role of social work change in postindependence urban societies? How was the burgeoning African social welfare workforce professionalised? We explore these questions through 
focusing on three main areas central to mining companies' attempts to shape mineworkers' families on both sides of the border: direct intervention into families; women's centres; and children and youth work. As well as tracing changes to social work programmes in this period by use of company and state archival materials, the chapter uses interviews with former community development officers, leisure and sports club officers in both the Zambian and Katangese Copperbelts to explain their own understanding of their role. ${ }^{2}$ Using these sources, the chapter investigates the ways in which their understanding of social intervention changed during this period, and explores how the provision of social welfare was influenced by their ideas about the role of companies in managing social change, gender and generational relations, and how they understood the changing role of 'custom' in postcolonial Copperbelt towns. This is not, however, a study of how effective these policies were in delivering social order in these towns, nor does it analyse the general reception of these programmes among urban residents.

We begin by briefly tracing the development of social provision on both sides of the Copperbelt in the early twentieth century, before turning to the justifications given for social welfare provision by companies. We then explore the Africanisation and professionalisation of the community development workforce, which occurred more rapidly than the Africanisation of technical and engineering positions in the mines. The chapter then analyses key areas of social work activity in family life and with youth and women. Brief explanations are provided of the welfare policies of the companies themselves, but the analysis focuses on the ways that social workers and community development officers themselves understood them. We also discuss changing perceptions among social workers of 'customary' practice and how these changed in the postcolonial Copperbelt towns. Finally, the chapter discusses the collapse of social provision with the decline of the international copper price and the mining industry in the 1980s and 1990s. While fragments of company responsibility towards the families of workers and ex-workers remain, social workers today see the collapse of these services as emblematic of economic and social decline, stressing both the benefits brought by company provision and the trauma caused by its sudden disappearance.

2 In this chapter, we draw from interviews with social workers employed by the BCK/ SNCC railway company as well as by UMHK/Gécamines and, in Zambia, the mine companies that were in 1982 consolidated into Zambia Consolidated Copper Mines (ZCCM). 


\section{The Origins of African Urban Social Welfare in the Copperbelt}

In 1928, Union Minière du Haut-Katanga (UMHK) decided to build a permanent African labour force living near the mines, rather than relying on migrant labourers. ${ }^{3}$ This decision made the family life of its workers a major company concern, as UMHK saw promoting marriage and family residence at the mines as a key way to maintain this permanent workforce. The company initially favoured the recruitment of married workers who would be accompanied by their families, and encouraged their single workers to marry. ${ }^{4}$ Quickly, however, company policy shifted to making sure that workers and their families lived in camp in the 'correct' manner, one that would aid worker productivity and development, secure peace and order, and ensure that workers' children were themselves educated to become productive workers, or wives of workers. ${ }^{5}$ Its policies and practices were shaped and enabled by the social interventionist policies of the Belgian colonial state, and by the Catholic Church's provision of schools and family services in mine camps. ${ }^{6}$

This was only possible because UMHK already exercised a high level of control over workers themselves. Originally they had to live in company accommodation, dwelling in mine camps presided over by company officials and 'malonda' (camp policemen), although by the 1950s mineworkers and their families were allowed - and sometimes encouraged - to live elsewhere. ${ }^{7}$ All camp residents or visitors needed to be registered. Alongside

3 The reasons for this policy are beyond the scope of this chapter. See the introduction to this volume, and the discussion in Donatien Dibwe dia Mwembu, Bana Shaba abandonees par leur Père: Structures de l'authorite et histoire sociale de la famille ouvriere au Katanga, 1910-1997 (Paris: L'Harmattan, 2001), pp. 12-17.

4 Dibwe, Bana Shaba, pp. 55-61.

5 Ibid., pp. 55-87.

6 For the uneasy triumvirate of Belgian colonial social policy, see Guy Vanthemsche, Belgium and the Congo, 1885-1980 (Cambridge: Cambridge University Press, 2012); for its natalist policy, see Nancy Rose Hunt, “Le Bebe en Brousse”: European Women, African Birth Spacing and Colonial Intervention in Breast Feeding in the Belgian Congo', International Journal of African Historical Studies, 21, 3 (1988), pp. 401-32. The specific application of these policies is discussed in Jean-Luc Vellut, 'Les bassins miniers de l'ancien Congo belge': Essai d'histoire économique et sociale (1900-1960)', Les Cahiers du CEDAF (Brussels: CEDAF, 1981); Bruce Fetter, The Creation of Elisabethville 1910-1940 (Stanford: Hoover Institution Press, 1976).

7 For evidence of UMHK encouraging its more senior African workers to live outside of mine accommodation, see 'A chacun sa maison', Mwana Shaba, 2, 1957. Jeanette 
these controls, UMHK provided services for workers and their families. It provided food rations, family accommodation, hospitals, schools, women's centres and street cleaning from the 1930s onwards. The quality and range of these services steadily expanded and, by the 1950s, came to include leisure centres ('cercles'), piped water and electricity. ${ }^{8}$ These benefits - or the threat of their removal - could also increase company power over workers and their families. Infractions, such as fights between neighbours, were punished by withholding pay, or the rations of the family members involved.

Union Minière du Haut-Katanga's social policies complemented, and extended, the colony-wide approach to intervention in African family life endorsed by the Belgian colonial state, in collaboration with the Catholic Church. Other large enterprises, particularly the rail company Chemins de fer du Bas-Congo au Katanga (BCK) - later Société Nationale des Chemins de Fer du Congo (SNCC) and then Société Nationale des Chemins de Fer du Zaïre (SNCZ) - took on significant roles in social provision for, and social control over, their workers and their families. The system established by UMHK, and extended in the postcolonial period by its successor company Gécamines, was, while not unique, certainly more pervasive, as the company provided a greater number of services and more generous family provision. Company requirements measured and regulated nearly all aspects of family life. For example, women were required to present their babies for weighing and health checks, primary school attendance was made compulsory, and women were incentivised to carry out domestic activities that they were taught to deliver at company-run classes.

In the Northern Rhodesian Copperbelt, continued hesitancy about worker stabilisation throughout the 1930s and 1940s meant that mine companies in general continued to treat their employees as temporary migrant workers, single men whose families supposedly remained in the village. ${ }^{9}$ Mine compa-

Kahamba and her husband lived in their own private house in the 1950s before her husband was appointed to a managerial position, and they were approved to move to La Mission, the majority-white management housing area. Interview, Jeanette Kahamba, Likasi, 17 July 2019.

8 This did not mean that UMHK workers accepted or were satisfied with the social conditions of the mine camps: Higginson describes a wave of unrest culminating in the 1941 mineworkers' strike: John Higginson, A Working-Class in the Making: Belgian Colonial Labor Policy, Private Enterprise, and the African Mineworker, 1907-1951 (Madison: University of Wisconsin Press, 1989), pp 181-90.

9 For the 'stabilisation' debate see H. Heisler, 'The Creation of a Stabilized Urban Society: A Turning Point in the Development of Northern Rhodesia/Zambia', African Affairs, 70, 279 (1971), pp. 125-45. 
nies therefore provided much less for their workers than in Katanga, but also played far less of a role in controlling or shaping workers' family lives. While many women did migrate to mines and some 'married' workers, these marriages were not in forms recognised by the mining companies. ${ }^{10}$ Little provision was made for the presence of permanent urban families before midcentury: family housing began to be built in the 1940s, but the provision of social welfare and education began to be taken seriously only in the 1950s. In contrast to the Belgian Congo, where the provision of urban services was understood as a proactive policy of societal management, the provision of social services in Northern Rhodesia began as a largely defensive measure. Urbanisation, it turned out, was unavoidable, and mining companies and government officials alike feared that unplanned urbanisation would adversely affect worker productivity and create social - and ultimately political - unrest. ${ }^{11}$ Colonial and company officials in Northern Rhodesia saw UMHK's social provision as a model, but an unachievable one. They believed that socialising workers and their families into urban circumstances was a profound challenge - one they might not be able to meet.

The 1950s was a period of growth in social provision across the Copperbelt that was part of a massive post-Second World War expansion in colonial state intervention encompassing economic growth and urban social welfare and development. ${ }^{12}$ Companies and local government embarked on a programme of housing construction, new schools opened under the authority of new African teachers, and social services - run by a network of church, voluntary service, local government and mine companies - expanded rapidly. Underlying these interventions was

10 George Chauncey Jr, ‘The Locus of Reproduction: Women's Labour in the Zambian Copperbelt, 1927-1953', Journal of Southern African Studies 7, 2 (1981), pp. 135-64, p. 137; Jane L. Parpart, 'The Household and the Mine Shaft', Journal of Southern African Studies, 13, 1 (1986), pp. 36-56, pp. 40-1; James Ferguson, Expectations of Modernity: Myths and Meanings of Urban Life on the Zambian Copperbelt (Berkeley: University of California Press, 1999), pp. 170-7.

11 National Archives of Zambia (hereafter NAZ), MLSS 1/12/5, Northern Rhodesia Council of Social Services 1967-68.

12 D. A. Low and J. M. Lonsdale, 'Introduction: Towards the New Order, 1945-63', in D. A. Low and Alison Smith (eds), History of East Africa vol. 3 (Oxford: Clarendon Press, 1976); Monica van Beusekom and Dorothy Hodgson, 'Lessons Learned? Development Experiences in the Late Colonial Period', Journal of African History, 41, 1 (2000), pp. 29-33; Frederick Cooper and Randall M. Packard (eds), International Development and the Social Sciences Essays on the History and Politics of Knowledge (Berkeley: University of California Press, 1998). 
an assumption that transition from rural to urban society necessarily involved the loss of rural patriarchal authority and a consequent decline in customary familial practices, leading to the emergence of an idealised modern nuclear family in which male wage earners were supported by wives who kept their homes and raised their children. The loss of this authority had to be compensated for by informed social intervention to manage this supposed transition, during which custom and modernity would interact in socially disruptive ways. Social science researchers and policy-makers worried about the disruptive effect on 'inter-ethnic' marriages of conflicting customs of their rural societies regarding, for example, the payment of 'bride price', polygamy and the inheritance rights of widows. ${ }^{13}$ High urban divorce rates were understood as a manifestation of this social disruption. ${ }^{14}$ In UMHK mine camps, polygamy was discouraged by the company's recognition of only one wife and her children as recipients of company rations and housing and, in 1950, was banned outright in Elisabethville's non-mine township. ${ }^{15}$

While Northern Rhodesian companies' provision of social services was belated compared with Katanga, within a few years a territory-wide council was coordinating social service provision by actors including churches, mine companies and European women's groups. Its members worried that the limited opportunities for education and jobs for teenagers was likely to contribute to delinquency and social unrest. A Homecraft Training Scheme served 'a very useful purpose in helping the African woman adapt to the western and urban civilisations'. ${ }^{16}$ There was general agreement that '[i]n any scheme the educated Africans must carry the message to their own people. They were essential co-workers. ${ }^{37}$

13 Benjamin Rubbers and Marc Poncelet, 'Sociologie coloniale au Congo belge: Les études sur le Katanga industriel et urbain à la veille de l'Indépendance', Genèses, 2, 99 (2015), pp. 93-112, p. 98.

14 Chauncey, 'Locus of Reproduction', p. 162.

15 J.Vannes, 'De l'évolution de la coutume d'Elisabethville', Bulletin du Centre d'Etude des Problemes Sociaux Indigènes, 32 (1956), p. 223-68. See also Nancy Rose Hunt, 'Noise over Camouflaged Polygamy, Colonial Morality Taxation, and a Woman-Naming Crisis in Belgian Africa', Journal of African History, 32, 2 (1991), pp. 471-94.

16 NAZ, MLSS 1/12/5, Northern Rhodesia Council of Social Services 1967-68 [incorrect dates at source], NRCSS, 'Report of the Chairman to the Sixth Annual General Meeting', 12 September 1960.

17 NAZ, MLSS 1/12/5, Northern Rhodesia Council of Social Services 1967-68 [incorrect dates at source], NRCSS Social Workers' Conference, 25 September 1958, Doctor Donnolly, Medical Officer of Health, Lusaka Municipality. 
In efforts to promote monogamous marriage and discourage sex outside marriage, the importance of female African 'welfare assistants' was recognised: the new Oppenheimer College of Social Services would from 1961 train an expanded cadre of professional African social workers. ${ }^{18}$ There was in such initiatives a tension between, on the one hand, the need for a cadre of 'advanced' urbanised Africans able to educate and socialise new urban residents; and on the other hand, the belief that urban migrants needed to be kept in touch with their customary culture during transition, and, linked to this, the assumption that educated Africans both understood custom and could manage its declining influence in a developmental way.

By independence, the provision of social welfare services - as a central part of a wider set of interventions ranging from housing to healthcare shaped the lives of company employees and their families in both Copperbelt regions. A new generation of African social workers inherited the contradictions of late-colonial social welfare policy rooted in the racialised assumptions outlined above. However, they brought to their practice a new set of professional and universalist ideals arising from their social work training coupled with an overriding commitment to the companies' aim of achieving a stable gendered order in its mine townships.

\section{Training and Professionalisation of Social Work after Independence}

The early independence period saw the steady replacement of European managers of social welfare provision - some of whom continued to hold senior positions until the 1970s - with a growing cadre of African social workers, themselves part of a much wider system of community services provided to mine and railway employees. In Katanga, nuns and other European women continued to play an important supervisory role in certain areas of social provision, overseeing African staff in women's centres and maternity wards for decades after independence, but they were now accompanied and gradually supplanted by secular African employees and managers. ${ }^{19} \mathrm{~A}$ new generation of educated young Congolese men were appointed

18 The college was named after Ernest Oppenheimer, the former head of the Anglo American Corporation, one of the major mining corporations on the Northern Rhodesian Copperbelt.

19 Interview, Charlotte Panga Kelita, Likasi, 16 July 2019; interview, Mme Séraphine, Likasi, 15 July 2019; interview, Mwepu Mudianga, Likasi, 15 July 2019; interview, Marguerite Luse Kibungo, Likasi, 9 August 2019 
to the position of chef de cité (Town Manager), the senior official responsible for overseeing both mineworkers and their families. ${ }^{20}$

The growing demand for additional social workers meant that many were initially recruited straight from secondary school and learned on the job, while they received further training. In Zambia, many of those who went on to work with adolescents were themselves young men (and later women), often the children of mineworkers who had grown up in mine townships, and were initially identified for their sporting abilities. In Haut-Katanga, professional training schools in nursing and education actively sought out new recruits at secondary schools. ${ }^{21}$ These professional training schools, sometimes run by UMHK/Gécamines, then sent students on internships to schools or hospitals, which quickly snapped up the new recruits. As one nurse, who started working at Gécamines in 1978 immediately after her graduation from the Gécamines-run nursing college in Kolwezi, remembered, 'everywhere, there was a need for workers'. ${ }^{22}$ Many new social workers moved from education into a specialisation in social work. ${ }^{23}$

By the 1970s, however social welfare officers in Zambia were steadily becoming more professionalised by the increasing provision of training courses: by diploma (one-year) courses in Social Work, Sociology or (in a later period) Pan-African Women's leadership course provided by the church-run Mindolo Ecumenical Foundation (MEF) and the statecontrolled Presidential Citizenship College at Mulungushi. ${ }^{24}$ Employees in both countries regularly attended a wide range of seminars and other forms of training: senior SNCC social worker Mwepu Mudianga recalled that there was training 'all the time, seminars all the time' ${ }^{25}$ Zambian trainees report instruction by instructors from a range of nationalities, including Western Europeans but also from the Eastern Bloc and the United States. The main Katangese employers seem to have provided much of their training in-house, reflecting their pre-existing capacity in the social sector, while also sending new recruits to state-run professional training schools. Astrid Bilonda, for instance, hired in 1975 after completing secondary school, was sent by Gécamines to the INPP (National Institute for Professional Training) for accelerated training to

Interview, Jérôme Kipili Mulungu, Likasi, 4 June 2018.

Interview, Matilda Mwinda Kabwe, Likasi, 15 July 2019.

Interview, anonymous woman, Likasi, 26 August 2019.

Mudianga interview; interview, Nicodème Nguza Yav, Lubumbashi, 23 August 2019.

Chishala interview.

Mudianga interview. 
be a hospital administrator. Throughout her career she was regularly sent for further instruction within Haut-Katanga. ${ }^{26}$ UMHK/Gécamines also sent some high-flying workers to attend training courses in Belgium. ${ }^{27}$ In both countries, such courses now drew on a characterisation of the socialisation of youth and family dynamics that was consciously universal, and no longer rested on the colonial notion that urban life presented rural African migrants with unique challenges reflecting their racial identity. ${ }^{28}$ Trainees returned to their communities equipped with what they felt were the necessary skills to intervene in urban social problems of townships, and empowered by their companies with the capacity to do so.

By the mid-1980s, this ongoing process of professionalisation meant that more aspirant recruits held degrees in relevant areas. A small number of Zambian trainees, such as Leonard Chola, were sponsored for degrees in Public Administration and Sociology, which enabled them to take up the most senior positions overseeing township services..$^{29}$ In Katanga, too, a small number of social service employees were hired with degrees, while others pursued degrees alongside their employment, with varying levels of company support, and recognition. ${ }^{30}$ The gradual professionalisation of the social welfare cadre, in which younger, more educated Africans were put in charge of older more experienced staff, sometimes led to tension. Josephine Lukwesa's appointment to a senior supervisory role was successfully resisted by older women who insisted that she lacked the life experience required, and she was appointed to a less senior job. ${ }^{31}$ In contrast Matilda Mwenda Kabwe, first as a teacher, then as a school head, and then as Gécamines Director of Education for Likasi and Kambove, recalled no difficulties from older (male) staff, who she was careful to treat with respect. ${ }^{32}$ Interviewees stressed the validity of

26 Interview, Astrid Bilonda, Likasi, 18 July 2019.

27 Interview, Agnès Njamba, Likasi, 16 July 2019.

28 Chishala interview; Joseph Tumba Menzu interview, Mufulira, 11 July 2019; interview, Kilufya Kasongo Apolline, Lubumbashi, 24 August 2019.

29 Interview, Leonard Chola, Kitwe, 4 July 2019.

30 Interview, M. Mukendi [pseudonym], Lubumbashi, 30 July 2019; interview, Eugène Mofya Makumba, Lubumbashi, 23 August 2019; interview, Nicodème Nguza Yav, Lubumbashi, 23 August 2019; Mudianga interview. Ms Mudianga's degree in Sociology, for which she studied while working, was not recognised by her employer (SNCC) because she had not received their permission to study.

31 Interview, Josephine Lukwesa, Mufulira, 8 July 2019.

32 Matilda Mwenda Kabwe interview. 
their professional training but equally the need to apply theory in a practical way to individual cases, using counselling and listening skills. ${ }^{33}$

\section{Post-Independence Perceptions of Social Welfare Provision}

The Copperbelt region provides a well-known and much documented case of company paternalism (see Peša and Henriet, Chapter 1), in which the older obligations of mine camps to manage the lives of their workers and their families meshed in mid-twentieth-century Africa with statist intervention to create a system in which companies became intimately involved with virtually every aspect of their educational, social and cultural lives. ${ }^{34}$ In both Copperbelt regions, the extensive provision of social welfare services is today recalled as evidence that companies were 'caring' for their workers and their families. ${ }^{35}$ Most interviewees thought that a company should care for its workers and their families, and that it also had the right to intervene in family life to ensure this. This was presented as a fundamental element of a company's role in the world, and by extension in how society should be structured. As one interviewee put it: 'Gécamines can't abandon social provision, social provision needs Gécamines' ${ }^{36}$

Equally important was the idea that the companies should promote peace and social harmony by ensuring that township life and that of its workers was not adversely affected by familial disputes. The motivation was, as senior social worker Mark Masumbuko put it, 'to put harmony into the township: the most important thing was that miners, when they came home, they should find a habitable situation. And that was our role. ${ }^{37}$ Masumbuko also linked domestic harmony to broader social peace within mining settlements:

\footnotetext{
33 Menzu interview.

34 For Haut-Katanga: Dibwe dia Mwembu, Bana Shaba and Benjamin Rubbers, Le Paternalisme en question: Les anciens ouvriers de la Gécamines face à la libéralisation du secteur minier Katangais (RD Congo) (Paris, L'Harmattan, 2013). For the Zambian Copperbelt see Ferguson, Expectations of Modernity and Patience Mususa, 'There Used to Be Order: Life on the Copperbelt After the Privatisation of the Zambia Consolidated Copper Mines', PhD thesis, University of Cape Town, 2014.

35 Interview, anonymous man, Mufulira, 11 July 2019.

36 Interview, Brigitte Mukasa Kiwele, Likasi, 17 July 2019.

37 Interview, Mark Masumbuko, Kitwe, 4 July 2019.
} 
If a miner knocked off, and he didn't find the wife [had] already prepared food, that would arise into talking. Or, if the wife was not at home, without telling the husband ... that would create problems. Or the miner himself knocks off, goes for a beer before getting home, he goes home drunk, that would create a problem. So, noise would start, and we would get involved. ${ }^{38}$

Community development workerVictor Chishala likewise asserted:'A happy marriage will make the breadwinner perform his duties successfully.' 39 Versions of this 'productivity' explanation were articulated by virtually all interviewees in Zambia.

Limited social services were provided by local governments in both Copperbelt regions: in health and education, but also services for youth and women. It was widely recognised, however, that the state lacked the capacity to provide the level of services provided by the mine and other large companies. Mining companies provided all the services the state offered, as well as those the state could not. In Katanga, for instance, Gécamines residential areas had better cleaning and public health services than urban areas served by local councils. ${ }^{40}$ As a state-run company, Gécamines also at times supported government social work efforts, for example by providing internships or even jobs for children trained in government social centres. ${ }^{41}$

\section{Social Welfare in Practice I: Family Intervention}

In the post-independence Copperbelt, direct social work was part of a much wider network of social provision. In Katanga especially, the 'social' department encompassed schooling and healthcare, as well as the youth and women's centres, leisure centres, company stores, maintenance and sanitation teams and policing that were common to both Copperbelt regions. Mine companies in Zambia did provide clinics and hospitals for their workers and, to a lesser extent, education, but these did not form a direct part of the holistic system of social intervention into family life that had evolved earlier in Katanga (see above).

On both Copperbelts, mining companies employed officials to investigate and attempt to settle intra-family disputes. As a worker's wage and benefits were conceived of as supporting a whole family, a failure of a man to provide that

\footnotetext{
38 Masumbuko interview.

39 Interview, Victor Chishala, Kitwe, 6 July 2019.

40 This was frequently referred to in interviews: see for example Godelieve Ngoie, Likasi, 26 August 2019.

41 Nguza Yav interview.
} 
support was an issue for the company. Mining companies and most workers agreed that being a good worker and a 'good man' - one who supported his family well - were connected. Equally, a wife who, though supported by the company, did not provide for her children, was a source of concern and potential intervention. Interventions were most commonly prompted by a wife's complaint that she was not receiving sufficient money from her husband's paypacket to feed the family or maintain the household. This could arise because he was drinking too much or keeping another woman, with whom he might have a second family. He might have even 'abandoned' this first family to live with another, often resident outside the company area.

In such a case, the wife of a male mineworker would, in Zambia, visit or telephone the social welfare/community development office, or, in Katanga, go to a social worker or straight to the chef de cité. ${ }^{42}$ The social worker might invite the husband to a meeting, but if he failed to attend or the case was deemed sufficiently urgent, he was summoned from his workplace (thus revealing the intimate relationship between workplace and community and the single company overseeing both) to address the charges (see Moise Simba's story, below). In a minority of cases husbands brought complaints about their wives for failing to maintain their households and for themselves drinking too much alcohol. ${ }^{43}$ It was also possible for a Personnel Officer, noting an underperforming worker, to contact a Social Welfare Officer to explore if this might be caused by a problem at home. Companies then, while empowering their male employees to act as the heads of their households, might sanction those workers if they failed in their duty to produce stable families and communities and to raise the next generation of company workers.

Social workers aimed to resolve disputes by facilitating discussions between spouses and seeking pledges of good behaviour: husbands were for example urged to give a fixed percentage of their salaries to their wives on pay day. ${ }^{44}$ When husband and wife disagreed about the cause of such problems, social workers would sometimes collect evidence from neighbours regarding the situation in the household. ${ }^{45}$ Looming over the counselling process were the possible disciplinary implications of non-cooperation. As Joseph Tumba Menzu put it: 'If an employee thinks he will lose his work he will come back. It was just one way of getting the family stable and the

42 Kiwele interview; Nguza Yav interview.

43 Kiwele interview.

44 Ibid.

45 Ibid. 
best of an employee. ${ }^{46}$ Interviewees did not see a contradiction in mediating between both parties: Menzu described himself as a 'shock absorber' in managing such conflicts of interests. ${ }^{47}$ Social welfare professionals interviewed have, perhaps unsurprisingly, a strong belief in the positive effects of these interventions, not only for the marriage but the workplace and for society as a whole. Chisala for example argued that a husband who stopped spending most of his money away from the home would, in changing his behaviour, ensure that the children would now have school uniforms, enabling their education. ${ }^{48}$

Ultimately, backed by the authority of the company - as employer and landlord - social workers or the chef de cité could arrange the payment of part or even all the husband's salary directly to the wife as a way of ensuring the family was properly maintained. ${ }^{49}$ The knowledge that one's employer was aware of such marital problems helped discipline male behaviour. ${ }^{50}$ Some workers would initially be resistant to 'interference' by company in their marital affairs but equally knew when they began employment that the social work officers were there. ${ }^{51}$ One head of social work for Gécamines in Likasi recalled some workers walking off angry at the proposal to dock their pay, but generally they came back a few days later pleading for their jobs. ${ }^{52}$

Social case work included not only cases of adultery but also of spousal abuse, witchcraft accusations and child abduction. Whereas in the colonial era instances of witchcraft might have been regarded as manifestations of a hangover of rural 'tradition', post-independence social workers treated them strictly as family or even legal matters. Cases that started in the social work department might end up in the local magistrates' court but the aim was to resolve them at an earlier stage..$^{53}$ In Katanga, social workers often saw their job as preventing divorce or separation, disruptive of the family order, so as to ensure that children were well cared for. ${ }^{54} \mathrm{~A}$ wife's adultery, however,

\footnotetext{
Menzu interview.

Ibid.

Chishala interview.

Masumbuko interview.

Chola interview.

Chishala interview.

Kiwele interview.

Chishala interview.

Kiwele interview.
} 
would often lead to a divorce. ${ }^{55}$ As Chishala explained, 'If a mineworker met an accident and the wife committed adultery, then it would be believed that the adultery caused the accident, to the point of ending the marriage. ${ }^{56}$

Company intervention into the internal workings of individual families reveals the limits of company support of patriarchal control. The nuclear family model on which the system rested assumed that a male worker should not only be able to control his wife, but even had a duty to society to do so. At the same time, married male workers were themselves expected to maintain a happy family home. The involvement of mine companies in family life was not always welcomed by male workers, who at times considered that their employer was interfering with their right to run their family as they saw fit. 'Moïse Simba', for instance, was sanctioned for his 'nonchalance' in responding to his wife's complaint to Gécamines that he had abandoned the marital home. Simba argued that 'this problem between my wife and me will be sorted at the level of the respective families, and not here in the town', an argument rejected by Gécamines officials. Their willingness to intervene in Simba's home life was, however, limited. They were unconcerned that Simba had a second wife, so long as he could live peacefully with, and provide for, his first wife, registered on his company documents. They were however concerned that he had allegedly beaten his first wife for complaining to the company, an affront to company authority. They were ultimately pacified by Simba's argument: 'I often corrected my wife because her behaviour is not good. ${ }^{57}$ In addition, in Katanga UMHK/ Gécamines demanded that children were cared for - and supervised by the company - in particular ways. Women were obliged to give birth in hospital where their children were weighed, given vaccinations and their mothers given advice. Alongside the provision of food rations, mineworkers' families were provided with free healthcare, primary and, for some students, secondary or vocational schooling. If a mother and baby failed to attend compulsory checks, the woman's husband (or, if the woman worked for Gécamines, she herself) would be called into their supervisor's office, and the worker's pay could be docked for non-attendance. ${ }^{58}$

55 Rubbers, Le paternalisme en question, p. 180; interview, Pascal Makombi, Likasi, 6 August 2019.

56 Chishala interview.

57 The names are pseudonyms. GCM Personnel Office, Likasi, Panda, Personnel File 085414/5.

58 Njamba interview. 


\section{Social Welfare in Practice II: Children and Youth Work}

As indicated above, early-childhood education had been an important focus of missionary and UMHK attention from the 1940s. Most educational theorists at that time argued for of a universalist model - that what children in Katanga needed was the same as children everywhere. They often directed scorn at African mothers' child-raising, but the message was clear that, with the 'right' education, African children could learn and be successful. To this end, foyers sociaux offered training for teenage girls and for workers' wives in childcare (see below), as well as housing kindergartens which put these ideas of 'scientific' early years education into practice.

After independence, this universalist mode of teacher training and practice continued in Katanga. One school director, explaining why she felt that Gécamines schools remained superior to other private schools, argued that Gécamines schools would not adopt bad practice simply to receive a child's school fees. If a parent came trying to enrol a too-young child in the school, she would send him or her away, telling them that 'psychologically' the child was too young for formal education. ${ }^{59}$ At kindergartens, this universalist mode was even more apparent. As one former teacher explained, the curriculum helped ensure that children learned the skills they needed for formal schooling and day-to-day life. They learned 'how to work together, to not argue, to know to ask forgiveness, and to not hit the others', as well as preparing to learn to read and write. ${ }^{60}$ This approach was designed to train a future generation of disciplined company workers, and the company systematically recruited many employees from its own schools.

In Zambia, while school education was generally the preserve of the post-independence state, company intervention focused on adolescent youth. Mine companies, like the Zambian Government, believed that youths needed to be kept busy because otherwise they tended towards mischief of various kinds, vandalism etc. By playing sports and games, attending youth clubs and receiving training, youths learned discipline, an acceptance of authority, and were able to apply this to other areas of their lives. In a context in which, by the 1970s, the number of new jobs in mine companies had stagnated, the provision of skills training enabled mineworkers' children to take up income generation opportunities, for example in carpentry, tailoring, mechanics, plumbing, electrical work or vehicle repair, and obtained employment in

60 Kilufya Kasongo interview. 
other companies or were able to establish small businesses of their own. ${ }^{61}$ Some mineworkers' children were hired by the mining companies, as in Katanga, but in Zambia there was a greater effort to train them in areas outside the mines. Efforts were also made to train and motivate young people to engage in farming, with the aim of encouraging them to grow crops in nearby rural areas. ${ }^{62}$

Sports and recreation officers did not simply wait for youth or their parents to approach them. Instead they actively would go into townships to look for and pick up 'roamers', who would otherwise cause a 'nuisance' and vandalise equipment; they then approached the parents with a view to engaging them in sports training. There was a tacit acknowledgement that some youth would not attend school but could find a suitable outlet via sports. Parents would also refer their own badly behaved children to social case workers. ${ }^{63}$ Through participation in both sports training and night schools, 'they changed their attitudes'. ${ }^{64}$ Moral instruction and socialisation into appropriate behaviour were always an important element of sporting programmes ${ }^{65}$ Some interviewees saw this process of socialisation as analogous to and implicitly replacing the socialisation of youth that would in the past have been provided by elders in rural societies. ${ }^{66}$

In explaining the provision of sports and youth activities, some interviewees articulated versions of the 'productivity' argument, above. They also suggested that they inculcated 'a sense of belonging' between the company and the mine township youth, who might for example protect the company because they regarded it as their own. ${ }^{67}$ Similarly, in Katanga, UMHK/ Gécamines sponsored sporting teams and competitions in order to provide entertainment and community for workers and their families. The moral and character-building elements of team sports were less strongly emphasised; instead they were activities that Gécamines supported as the patron of the community. ${ }^{68}$

61 Masumbuko interview.

62 Interview, anonymous man, Mufulira.

63 Chishala interview.

64 Masumbuko interview.

65 Menzu interview.

66 Ibid.

67 Lukwesa interview.

68 Interview, Dieudonné Mupanga, Likasi, 5 August 2019. 


\section{Social Welfare in Practice III: Women's Centres/foyers sociaux}

Women's centres in both Zambia and Katanga provided forms of post-school education and instruction in what were evidently explicitly gendered forms. In line with the assumption, discussed above, that township residents needed to be taught how to be modern and urban, they were initially designed to train women in domestic tasks - cooking, sewing, knitting, tailoring and raising children. Implicit in the need for training was the sharp difference in the socialisation of young women in town compared with rural areas: in the village, they would learn necessary skills from older female relatives, and the specific skill set required in town - for example, managing a cashbased household budget, or providing meals and a clean domestic environment for a husband working in waged employment - was itself different. ${ }^{69}$ One (male) social worker recalled: 'There they would learn to cook, keep the house clean, knitting, a lot of women's activities. ${ }^{70}$ Training women in managing a household budget was equally seen as a key contribution to maintaining family harmony and avoiding marital conflict. ${ }^{71}$ The actual acquisition of skills was in some respects secondary to persuading young women to take responsibility for the household. ${ }^{72}$

Yet by the 1970s, and increasingly from the 1980s, these activities developed a dual use, i.e. to generate income. Whereas male wages were initially assumed to be sufficient to raise a family, it was increasingly recognised that women's earnings - usually through some form of trading - were an important source of income to the household and to the woman in particular. Women, interviewees reported, greatly appreciated the skills they gained. ${ }^{73}$ Some husbands had to be persuaded to allow their wives to take these courses but in general, the acquisition of such skills was regarded as beneficial to the household. ${ }^{74}$ Women who received training in child rearing, cooking and sewing, whether in primary school, as teenagers at 'écoles menagères', or as adults at 'foyers sociaux', recall the skills they gained with great pride. Astrid Musambi attended a state 'école menagère' for three years after primary school in the early 1970s, which she credited for giving

69 Masumbuko interview.

70 Ibid.

71 Lukwesa interview; Masumbuko interview.

72 Lukwesa interview.

73 Masumbuko interview.

74 Chishala interview. 
her the skills to provide a good home environment for her husband's seven children from his first marriage. She used these skills to decorate the home, arranging artwork and producing embroidery to decorate sofas, tables and beds. Her neighbours paid her to produce similar work. As she explained, 'you make your bed, and if someone sees it, they say "Oh! The cover is perfect!"'75 She also enrolled her step-daughter, just out of primary school, in a Gécamines école menagère, and recalled happily that after three years there 'she [knew] how to knit jumpers, [and] dresses, she start[ed] to sell tablecloths, [with the] foyer she knew how to do all the work. ${ }^{76}$ By developing these skills, some women succeeded in developing independent businesses and thereby empowered themselves within the gendered constraints of Copperbelt society.

By the 1980s, domestic skills courses were still being provided, but were now presented mainly as increasing women's opportunities to earn a living in a context of growing economic difficulties, to the extent that their original 'domestic' role had been largely forgotten. Women's centres, some witnesses recall, also provided opportunities for unofficial forms of socialisation and the sharing of advice among women: one asserted that women were taught how to space their children without the use of contraception, which was not widely available. ${ }^{77}$ By that time a changing international and local political context meant that 'women's rights' had in Zambia became part of the training courses: this did not mean full equality or that wives should not obey their husbands, but limited efforts were made to help educated women assert their right to paid employment as a positive contribution to the household, and to balance their own health against giving birth to children. ${ }^{78}$ On occasion, generational divisions led some older residents to criticise the imposition of what they perceived as 'Western' ideas regarding gender and family relations. Josephine Lukwesa, in her work with the women's programme, challenged older women by drawing an analogy between new ideas about gender and the Western-type school education they commonly desired for their children and grandchildren. ${ }^{79}$

75 Astrid Musumbi interview, Likasi, 6 August 2019.

76 Musumbi interview.

77 Masumbuko interview.

78 Lukwesa interview.

79 Ibid. 


\section{Beyond Custom: Building and Maintaining Mining Families}

Underlying the need for social intervention in the colonial period had, as we have seen, been the assumption that 'traditional' African family life, supposedly rooted in patriarchy and essentially unchanging rural societies, was radically challenged by urbanisation. ${ }^{80}$ Postcolonial social workers however broke from such rigid divisions between 'traditional' and 'modern' life that informed colonial conceptualisations of social intervention. Some however, particularly in Zambia, did discuss the ways in which changed social circumstances affected the ways in which 'custom' was observed. In both Katanga and Zambia, company educators, healthcare staff, youth workers and social workers, did not see their jobs so much as managing a dangerous, but necessary, decline in tradition, or of carefully shepherding new urbanites. Instead, they focused on building strong families and communities, on providing necessary services, and above all on maintaining social order.

Succeeding generations of Copperbelt residents adapted the traditions of marriage and family they learned from their parents, keeping aspects that appealed to them and seemed to still be relevant, and discarding others. In the main, this was done without the direct intervention of social workers or of other company officials. While statistical evidence is not available, research suggests that marriages between members of different 'ethnicities', for instance, became increasingly popular on the Katangese Copperbelt from the 1950 and 1960s, and in Zambia from the late 1970s and 1980s. Élise Matanda, a Gécamines nurse of Katangese origin, remembered her parents' disapproval in the 1970s when she wanted to marry a man from a Kasaian family. Nevertheless, she told them, 'I love him. That's it!' and they got engaged ${ }^{81}$ With the support of her elder sister, a sewing teacher, she persuaded her parents to drop their objections, although they did specify that the Kasaian custom of 'tshibau' (concerning punishment for adultery) was not to be practised.

Similarly, the Kasaian custom of a 'stage matrimonial' - a period where a wife would live with her in-laws, and work for them - was maintained or abandoned according to the life circumstances of the couples and families concerned. Élise Matanda, stayed with her Kasaian in-laws for a month after her marriage in their house in Likasi, which was not an easy experience.

81 Élise Matanda interview, Likasi, 16 July 2019. 
'You wake up at 5am', she recalled, 'you clean the house ... yes, it is truly work. ${ }^{82}$ In contrast, Annie Mwenda, an SNCC nurse who also married in the 1970s, moved in with her husband straight away, without a stage, as her in-laws were based far away in Kinshasa. ${ }^{83}$ As new couples and their extended families negotiated arrangements that worked for them, they were generally left untroubled by social workers, whose interest in marriage was restricted to ensuring that registered wives and children were provided for, and that workers' wives had the skills to maintain a suitable home. ${ }^{84}$

Social workers we interviewed thus recalled little evidence during this period of major problems arising from clashes between different ethnic ideas regarding either marriage or youth socialisation. Concerns remained that family conflict might arise because some wives, newly arrived from the village, struggled with town life because they could not read or write or because they could not fulfil their roles as domestic hosts. These skills were precisely those that could be learned at women's centres. ${ }^{85}$ Most social workers were confident that mine township residents could learn about, adjust to and manage potential differences in 'custom' as the influence of the village on their families diminished. Some 'customary' activities, for example the initiation of children into adulthood, now 'was part of life in town. No-one went back. ${ }^{96}$ Any concerns centred not around the customs themselves, or their potential incompatibility with town life, but rather around the necessity of maintaining peace and order in the mine townships. Initiation ceremonies in Zambia, for example, had to be contained in private residences to avoid music and noise disturbing the wider population. ${ }^{87}$

Although post-independence African social workers were far less exercised about 'custom', mine company policies did still try to shape mining communities and families in distinct ways. As in the colonial period, mine and other companies continued to provide housing and other services within an implicit nuclear family framework. In both Zambia and Congo, companies still allowed the registration of only one wife, so if a man was

\footnotetext{
82 Ibid.

83 Annie Mwenda interview, Likasi, 15 July 2019.

84 Mudianga interview. In discussing why they did or did not take a stage, no interviewee mentioned company preferences. This silence was matched by contemporary and former social workers, foyers workers, and chefs de cité, who instead discussed family intervention in terms of distributing a section of a recalcitrant husband's wage to his wife and children, and providing classes in domestic skills.

85 Mudianga interview.

86 Masumbuko interview.

87 Chola interview.
} 
polygamous, 'you marry outside the system of the mines' ${ }^{88}$ In Congo, this meant that a second wife (and, until a change in family law under Mobutu, her children) was not entitled to company-provided medical care, housing or schooling. ${ }^{89}$ Nevertheless, social workers interviewed did not regard polygamy as an inherent social problem and, consistent with their general approach, would only intervene if polygamy led to conflict between the wives..$^{90}$ In Zambia, there were fewer benefits awarded to workers' families, but official registration was still important for housing allocation, and for benefits in the event of a husband's death.

Social workers and other company officials took a similarly relaxed approach to extended family members. Before independence, companies had restricted how long extended family members could stay with family in mining areas. After independence, these controls were relaxed in both countries, despite occasional memos from Gécamines officials decrying the presence of non-Gécamines kin in company housing. ${ }^{91}$ The vast majority of Gécamines workers seem to have hosted and supported extended family. ${ }^{92}$ As one nurse explained: 'I haven't been alone in my house since I started working for Gécamines [in 1978]. ${ }^{93}$ Social workers and other company officials were no longer concerned with maintaining a strict separation between Gécamines families and their non-Gécamines kin, although which family members were provided for was controlled through an intricate bureaucracy. ${ }^{94}$

\footnotetext{
88 Masumbuko interview.

89 This 1987 change in family law is discussed in Dibwe, Bana Shaba, p. 119.

90 Chola interview.

91 One memo informed managerial staff that they could not host people outside their nuclear families in their Gécamines houses, in order to maintain calm and security and avoid theft: GCM Likasi Personnel archives, 'Avis au Personnel de Cadre de Likasi', Likasi, 13 June 1972. However, no interviewees - employees or management - ever mentioned any restrictions on this after independence, and the vast majority of them hosted extended family members for long periods of time. A 1988 report recorded zero permits being granted for temporary hosting of visitors, further suggesting that this supposed rule was completely disregarded in practice: GCM Likasi Personnel archives, Bureau du Personnel Panda, 'Rapport mensuel mois de septembre', Panda, 4 September 1988.

92 For example, Mme Séraphine interview; Charlotte Panga Kelita interview.

93 Anonymous woman interview, Likasi.

94 GCM Personnel Office, Likasi, 'Proces-verbal de la reunion des services administratives du Département du Personnel' Jadotville, 16 April 1967. This documents the company's attempts to computerise the personnel and family records, to clarify family relationships, to keep track of where children were living, to iron out inconsistencies and to provide information on vaccinations to the medical office.
} 
On occasion, orphaned younger siblings or nieces and nephews might be approved as 'charges' of a Gécamines worker, and granted company support, and in some cases Gécamines might pay towards medical care of other resident family members. ${ }^{95}$ Otherwise, Gécamines workers had to pay to educate and feed their extended family members. ${ }^{96}$ In Zambia, the direct surveillance of households was also significantly reduced in the independence period. The number of residents, or the number of children accessing education, was not limited or closely monitored, and the internal composition of the mineworker's 'family' was not policed as long as conflict did not arise. ${ }^{97}$ The lack of services analogous to those provided by Gécamines meant the company had far less concern about classifying who, precisely, were the worker's family.

\section{Decline and Fall: Nostalgia for Company Welfare}

In the late 1990s and early 2000s, as the Copperbelt's loss-making mine companies were privatised, social service provision largely collapsed..$^{98}$ In both Zambia and Katanga, housing - formerly provided by the mine companies - was distributed to sitting tenants. Workers who did not have company accommodation, instead receiving a housing allowance, were allocated company-owned land, sometimes on former playing fields, to build their own houses. Company oversight of the lived environment declined, with the ending of company-run street cleaning and public hygiene campaigns. In Katanga, the vast majority of the mining workforce was laid off in the early 2000s - a lay off which included teachers, nurses and social workers. ${ }^{99}$ Former workers and their families now needed to pay to visit the much diminished (in both quantity and quality) Gécamines hospitals, while in Zambia former workers had recourse only to the

95 For example, Njamba interview. See also, GCM Personnel Office, Likasi, 'Kapinga Ngelula, acces d'un parent aux soins médicaux', 1974. In this case, a worker's widowed mother was granted free medical care.

96 Interview, Stéphanie Matoba, Likasi, 8 August 2019; Mme Séraphine interview; anonymous woman interview, Likasi.

97 Chola interview.

98 For explanations of this financial collapse and privatisation process see Alastair Fraser and John Lungu, For Whom the Windfalls? Winners and Losers in the Privatisation of Zambia's Copper Mines (Lusaka: Civil Society Trade Network of Zambia, 2007); and Rubbers, Le paternalisme en question, pp. 49-59.

99 For more on the 'Départ voluntaire' and the trauma it caused, see Rubbers, Le paternalisme en question, pp. 99-107. 
local government welfare services, themselves badly hit by the loss of mine company revenue. Townships that were once the preserve of company employees and their families were now mixed, with houses sold or let to families who had no connection to the company; interviewees universally contrast the order and cleanliness of the past to present-day disorder, crime and unsanitary conditions (see Straube, Chapter 7). ${ }^{100}$.

Interviewees typically divide their descriptions of social services into the years before 'the crisis', when, broadly speaking, social welfare provision continued to operate at a high level, and afterwards, when only fragments of provision remained. Some interviewees did, however, volunteer that there were some changes in the 1980s and early 1990s: services, such as sports team membership, were now charged for at a higher level, and the physical infrastructure of hospitals, schools and youth centres began to decline. Similarly, Alick Tembo recalls there were already shortages in sports equipment and transport at this time. ${ }^{101}$ Certainly, archival evidence suggests that social service and company welfare provision was already in decline by the 1980s, and it is noteworthy that the memory of this decline is today closely associated with the break up of ZCCM and the 'crisis' of Gécamines associated with the political and military conflicts and redundancies of the 1990s and early 2000s.

Despite the closure of the foyers and their SNCC equivalents, there are today in Katanga a few company-supported centres with similar functions. Gécamines, consistent with its continuing role (compared with ZCCM-IH) runs social services centres in many of its former camps, which offer lessons in cooking, knitting, sewing, housekeeping, decoration and household budgeting. These centres are specifically for those who have missed out on education elsewhere, whether teenage mothers or those whose education was disrupted by financial crisis. ${ }^{102}$ They also no longer serve just the families of Gécamines workers, but also needy people from the general area. Given the location of the centres de promotion sociale in Gécamines camps, and the massive decrease in the Gécamines workforce, many of the "noncompany' attendees had a long family connection with the company. For Brigitte Mukasa Kiwele, the head of social services for Gécamines at Likasi, the purpose of the centres remains to help the advancement of society in

100 The popular memory of decline and nostalgia for company paternalism is analysed in Rubbers, Le paternalisme en question and Mususa, 'There Used to Be Order'.

101 Tembo interview.

102 Kiwele interview. 
general. ${ }^{103}$ In Zambia, mine companies continue to provide limited health and recreational services for their much diminished workforce and for some of their retired and retrenched workers, but not for their extended families. At least one privatised mine company, in Mufulira, employs a welfare officer to assist with the domestic problems of its workers, a conscious if small-scale reflection of the past. Some churches have taken over welfare centres and are providing facilities for income generation via activities such as sewing, but at a greatly diminished level. The continuing provision of and appetite for social welfare provision long after the heyday of corporate community development programmes is arguably the greatest evidence of its internalisation and Africanisation by Copperbelt communities.

For most former workers as well as for the social workers we interviewed, the loss of company social services was wrenching; they see today's urban society as less secure and less ordered than in the past, with children and youth struggling, and bringing disruption. In Zambia, former social welfare officers pointed out during interviews that the land on which football pitches and social centres once stood has been sold for housing: 'Our children in the township have nowhere to go.' ${ }^{104}$ They believe this has contributed to drinking, vandalism and crime, carried out by young people. The legacy of earlier investment in youth development is however identifiable in small businesses run by their former trainees, now in their middle age. ${ }^{105}$ Thus, the current decline enables social workers and community development officers to look back uncritically to a time when they played a vital role in maintaining societal and familial order, in a form entirely unconnected with the colonial origins of these policies.

Certainly, some residents of company areas explicitly argue that company service provision encouraged a dangerous dependency that made it difficult for mineworkers to manage their own affairs when services declined (see Peša and Henriet, Chapter 1). 'It was good, but in some ways it was bad, because Gécamines accustomed us to getting things free', recalled Dieudonné Mupanga, a former Gécamines worker who had spent his whole career in social provision, first as a teacher and then at the canteen, managing the distribution of food and other goods to workers' families. ${ }^{106} \mathrm{~A}$ former housing officer in Zambia likewise argued that the company provision of comprehensive services left employees ill-prepared for managing their own

103 Ibid.

104 Masumbuko interview.

105 Chola interview.

106 Mupanga interview. 
affairs when that support was removed. ${ }^{107}$ In general however, for the vast majority of social workers the crisis has reinforced their belief and even pride in the system of company oversight and intervention into family and community life for which they were once responsible.

\section{Conclusion}

This chapter has argued that the extensive provision of social welfare services in Copperbelt company townships, developing first in Katanga in the 1930s and then expanding rapidly across the region from the late 1940s, rested on a distinctive set of colonial ideas about African society and its supposed transition from rural to urban existence, which, while drawing on wider global notions of company paternalism and developmental intervention, combined these with specific racialised and gendered notions to shape the distinct form of social intervention practised in the late-colonial Copperbelt. This intervention increasingly centred on African social workers who were (by ancestry) informed about rural customary practices regarding familial and marital relations and (by training) able to train Africans into new nuclear family roles.

In the years after political independence, African social workers, trained in universalist forms of social intervention and employed by nationalised companies, rejected the notion that residents of Copperbelt company towns were experiencing any such transition or that 'custom' presented any particular challenge to the communities in which they worked. Rather, they understood social conflict - whether marital disputes, juvenile delinquency or housewives in need of domestic training - as resolvable by intervention, training and socialisation into the appropriate norms necessary for urban living anywhere. While these social interventions were highly gendered and initially continued to turn women into 'housewives' they came to provide opportunities for income generation and independent employment for some women, not least the social workers themselves. What many would see as an authoritarian corporate regime that policed the 'private' lives of workers and their families was justified as evidence of company benevolence, as contributing to what were for them the inherent goods of industrial productivity and social peace. The subsequent drastic decline of social provision on the Copperbelt has only reinforced their belief that their actions were in the interests of the communities they believed they served.

107 Interview, anonymous man, Kitwe, 5 July 2019. 